\title{
Histiocytoid Breast Carcinoma
}

National Cancer Institute

\section{Source}

National Cancer Institute. Histiocytoid Breast Carcinoma. NCI Thesaurus. Code C157235.

A rare variant of invasive lobular breast carcinoma characterized by the presence of histiocyte-like malignant cells with pale cytoplasm forming sheets or linear patterns. Apocrine differentiation may be present. It usually has an aggressive clinical course. 